\title{
Sugude, sotsiaalsete suhete ja koloniaalvägivalla kujutamine Eduard Vilde ajaloolise triloogia esimeses romaanis
}

\author{
TIINA KIRSS
}

$\mathrm{B}$ ernard Kangro sõnutsi tegi 1890. aastail ning sajandipöördel eesti algupärane romaan „esimesi arglikke samme, või õigemini, pikem jutustus hakkas tiitli all kandma pretensioonikamat liignimetust" (Kangro 1940: 332). Eduard Vilde nn ajaloolist triloogiat, romaane „Mahtra sõda” (1902), „Kui Anija mehed Tallinnas käisid” (1903) ja „Prohvet Maltsvet” (1908), tuleks seega pidada mitte kitsalt ajaloolise romaani alustekstiks eesti kirjanduses, vaid eestikeelse romaanivormi kinnistajaks üleüldse. ${ }^{1}$ Kuid ajaloolise romaani mõiste raames võiks Vilde triloogiat käsitleda mitmest aspektist: 1) histoorilisuse ning fiktsionaalsuse suhted; 2) lähiminevikust kirjutamisega kaasnev avatus mitmesugustele suulistele ning kirjalikele allikatele, sellest tulenevalt ka teksti krobeline ehk kirju faktuur; 3) anakroonia probleemistik romaani kui teksti ülesehituses. Lisaks võib Vilde triloogiale rakendada Ann Rigney käsitlust ajaloolise romaani olemuslikust hübriidsusest. Rigney väitel lõimitakse ajaloolises romaanis kokku ajaloolise teadmuse ning fiktsionaalse jutustuse elemente kolme strateegia kaudu: selektsioon, transformatsioon ning täiendamine (Rigney 2001: 22-23). Esimene nimetatud probleemidest, histoorilisuse/fiktsionaalsuse suhe, on ajaloolise romaani kaasasündinud probleem, mida pikemalt arutas oma kuulsas, 1850. aastal ilmunud essees „Del romanzo storico” Alessandro Manzoni (1984), kelle arvates ajalooline romaan oli väärvorm, mis oma esteetilise ebatäiuslikkuse tõttu varsti end ammendab ja välja sureb. ${ }^{2}$ Histoorilisuse/fiktsionaalsuse probleem ei piirdu tõe ning tõenäolisuse küsimusega, vaid kätkeb mitmeid alateemasid, näiteks autori allikakriitilisust oma jutustaja loomisel (too võtab sageli tagasihoidliku „koostaja” või „kadunud üriku avastaja" rolli), anakronisme tegelaskõnes või kujuteldud maailmas ja eessõnade ning muude paratekstide funktsiooni seoses romaaniteksti endaga.

Käesolev artikkel üritab lähemalt vaadelda ühte aspekti Mahtra ülestõusu representeerimisel romaanis „Mahtra sõda”: kujutatud sootsiumi sisemist heterogeensust. Avaliku teatrilava taga Mahtra mõisas asub küla, selle sees talupojaperekonna privaatne ruum - see ruum, mida ülestõusu eelõhtul

\footnotetext{
${ }^{1}$ Oma Bornhöhe „Tasuja” käsitluses ei määratle Eneken Laanes „Tasuja” kirjanduslikku žanrit (näiteks jutustus ehk Erzählung), kuna see küsimus on talle vähem oluline kui „Tasuja" roll kultuurimälu monumendina. Artiklis ta siiski käsitleb XIX sajandi eestikeelset ajaloolist proosat Franco Moretti „rändavate vormide” raames ning vaikimisi paigutab Bornhöhe „Tasuja” „moodsa romaani” tekkimislukku (Laanes 2012: 490).

${ }^{2}$ Manzoni pessimism ajaloolise romaani tuleviku osas on vastuolus tema enda 1827 . aastal ilmunud suurromaaniga „Kihlatud”, mida Georg Lukács hiljem pidas ajaloolise romaani kui žanri üheks täiuslikumaks näiteks.
} 
peetakse liiga kalliks, et seda tormaka vastuhakuga purustada. ${ }^{3}$ Vilde romaani poeetika tõstab jõuliselt esile soolised aspektid nii küla kui ka mõisa ühiskondlikus elus, valgustades kirjeldavalt ning analüütiliselt sotsiaalse korra soolist diferentseeritust ning koloniaalse-imperiaalse masinavärgi toimimist. Mitte ainult ei sekku mõisnik perekonnasuhete korraldamisse (abielude sõlmimine), vaid talutüdrukute seksuaalne ahistamine ning vägivald, mille eest neil pole ei kaitset ega juriidilist eestkostet, lööb kiilu tütarde ning neid paratamatult kaitseta jätva perekonna vahele. Ka romantikal on „Mahtra sõja” poeetikas oluline osa, mis ei kuulu mitte niivõrd ajaloosündmuste rekonstrueerimise, kuivõrd fiktsionaalsuse registrisse, toimides Rigney skeemi järgi „täiendusena” (ingl supplementation). Kaks romantilist liini (Miina/Päärn ning Juliette Marchand/Herbert von Heidegg) ei ole välja pakutud ainult lugeja meelelahutusena, vaid vahendina, mille kaudu mudeldatakse võimalusi ja piire ning osutatakse lootusrikkamale kaugtulevikule. Rõhutagem, et tähelepanu soolisele aspektile Vilde romaanis on tõhus, läbiv ning laiapõhjaline nagu ka Zola kuulsamates romaanides ${ }^{4}$ ega piirdu ainult nais- ja meespeategelaste romantiliste suhetega, mis justkui lahendaks hõlpsalt ühiskondliku ebaõigluse. Eraldi käsitlust vajaks teine aspekt Vilde romaanis kujutatud sootsiumi heterogeensuses: „Mahtra sõjas” kujutatud sotsiaalne struktuur, mõisavõimu poolt kehtestatud hierarhia (talitaja, kubjas-kilter-aidamees, peremees/teomees, toapoiss ja tüdruk). Teisalt võib rakendada skaalat indiviidist kollektiivini, mille ühes otsas on indiviidid: fiktiivsed peakangelased (Miina, Päärn, Juliette Marchand), ajaloolisest allikmaterjalist romaani tegelaskonda kaasatud sõja kaks juhti (Peeter Olander, Ants Tertsius). Kollektiivset dimensiooni näitab Vilde algselt tegelastekobarate nimetamisega, olgu siis tööl või koosolekul, sarnaselt Zola romaanide massistseenidega, kus eralduvad välja väikesed grupid (bandes), kelle tegutsemist lähemalt jälgitakse (Schor 1978: 10). ${ }^{5}$ Suurimad kollektiivsed kooslused ilmuvad romaani avapeatüki rehepeksustseenis ning Mahtra ülestõusu võitlusstseenides. Paari tuhandet talupoega, kes ümberkaudsetest mõisatest ning valdadest Mahtrasse kogunesid, võib juba nimetada „massiks” või vähemalt koosluseks, mis käitub massi moodi. Mahtra sõja traagika joonistub teravalt nende osavõtja-

\footnotetext{
${ }^{3}$ „Perekondlik õnn oli ju nende vaeste tööorjade ainus vara, armastus naise ja lapse vastu nende ainus ülevam aime. Naine ja laps hädas ja ahastuses - jah, see mõjus” (ptk 23, lk 328). Pastor Bergi hoiatuskõne suhtes Mahtra sõja eelõhtul on kõrtsis istuvad talupojad tõredad. Osutamine ülestõusu võimalikele tagajärgedele nende perekondadele on ainus osa pastori kõnest, mida nad kuulda võtavad, oma kurssi siiski muutmata. Käesolevas artiklis tsiteerin „Mahtra sõja” neljandat trükki ehk Orto kirjastuse kooliväljaannet 12. (Orto: Vadstena, 1949). Et lihtsustada artikli jälgimist ka teistes lugejale kättesaadavate editsioonides, on tsiteeritud passuse juurde märgitud peatüki number.

${ }^{4}$ „Germinal” (1885), „Nana” (1880). Vilde mainib Zola lugemist vaid möödaminnes, autorite loetelus, mis teda on „ergutanud” ning talle „teed näidates ... mõjunud” elulooülevaates M. Kampmannile 1912. aasta lõpul (Vilde 1957: 438). Suure tõenäosusega luges Vilde Zolad saksakeelses tõlkes.

${ }^{5}$ Mahtra sõjas osalenute (nii langenute kui ka karistatute, kokku 77) elulugudest on hiljuti konspektiivselt kirjutanud Rait Talvoja, kes aga dokumentides nimetatuid ei võrdle ega seosta Vilde romaani tegelastega, välja arvatud üks huvitav korrelatsioon, mis puudutab Üleka (Üleallika) Jüri Silda Purilast: „Tänu selle uurimuse tegemisele avastasin veel ühe Mahtra sõja ohvri, see on Üleka ehk Üleallika Jüri Sild Purilast. Nüüd on neid teada senise 11 asemel 12. Eduard Vilde räägib oma romaanis Ülleka Jürist kui kapten Bogutski ühest mahalööjast, kes siis mõni aeg hiljem end Purila jõkke uputas” (Talvoja 2009: 129). Täiendavad andmed leidis Talvoja Juuru kiriku surmameetrikast (Talvoja 2009: 129).
} 
te nägudele, kes pärast palagani ehk „võidupidu”, sõdijate jõugu lagunemist ning hirmunult rettutõmbumist äkitselt tajuvad end rängalt karistatavate või sandistatud üksikisikutena, kelle tegude tagajärjed kanduvad üle ka nende peredele. Enne põhiprobleemi analüüsile keskendumist on asjakohane lühike seletus romaani ülesehitusest ning valmimisprotsessist.

\section{Romaani saamislugu}

Herbert Salu väidab oma Vilde ajaloolisi romaane analüüsivas doktoritöös, et Vilde ei näinud „Mahtra sõja” kirjutamise eeltööga vaeva mitte huvist mineviku vastu, vaid soovist kaasa rääkida päevaprobleemides, arvestades kehtivaid trükitsensuuritingimusi (Salu 1964). Lähimineviku käsitlemine ilukirjanduslikus vormis võimaldas arutada olevikus edasi kestvat vägivalda mõisniku ja talupoja võimusuhetes ning takistada kirjandusliku teksti kaudu nende teemade avalikkusest mahakustutamist ning mahavaikimist. Joonealune järjejutt või följeton oli väljund, mille kaudu sai võimalikuks strateegiliselt avada ajakirjanduse uksed tabuteemadele: „Olevik eriti oli tulekardetavaks tunnistatud. Võis ju eesti lehes üksikust mõisnikust vahel ka halba teatada - et ta kuskil taas tõstnud talupoegade renti või võtnud mõnelt vallalt koolimaa ära jne. Kuid süsteemist ja institutsioonist sunniti täiesti vaikima. Olevikku ei tohtinud paljastada, pidi siis katsuma minevikku paljastada, et kaudegi luua - õigemini kohendada ja korraldada - rõhutud massides vihkavat meeleolu kõige vastu, mida see ammuiganenud süsteem kurja ja kurba oli soetanud" (Vilde 1957: 271).

Talupoegade rahutuste kujutamise heterogeensust eesti kirjanduses ei ole sügavamalt uuritud. . Talupoegade mäss, rahvakeeli „sõda”, mida Vilde kujutab, pole mõistagi kitsalt kohalik ega rahvuslik, vaid rahvusvaheline, kui mitte ülemaailmne nähtus. ${ }^{7}$ Vene impeeriumi jaoks toimusid Põhja-Eesti talupoegade rahutused kevadel 1858 samal ajal kui riigivõimule murettekitavad, üha sagedamad agraarrahutused mitmetes sise-Venemaa kubermangudes (Kahk 1958: 92-93).

Rahutused, vastuhakud ning mässud on kollektiivsed tegutsemisvormid, mida võivad ajendada kumuleeruv meeleheide, pilgeni täis saanud karikas ning erimeelsusi ületava raevu kaudu vormunud solidaarsus. Rahutuste „spontaansus" ehk stiihilisus on uurijate arvates siiski näiline ja petlik, kuna mässu puhkemise eel sageli püütakse organiseeruda või leida vähemdrastilisi lahendusi, mis säästaksid inimelusid (Hobsbawm 1959: 2, 5; Kahk 1958: 104-105). Kuna rahutused ning mässud lõpevad pea eranditult nurjumisega, raskete

${ }^{6}$ Mälumonumentide kontekstis vaidlustab Kersti Lust Jüriöö ja Mahtra näidete võrdväärtustamist kultuurimonumendi ehk metanarratiivi ehituskividena: „Sündmused, mida me tunneme Jüriöö ülestõusu nime all, kätkevad endas suuremaid eeldusi kujuneda rahvuslikuks müüdiks. Mahtras toimunust kirjutades saab autor anda oma fantaasiale hoopis vähem ruumi kui jutustades Jüriöö sündmustest, mille kohta on usaldusväärset kirjalikku teavet säilinud väga napilt ... Mahtra sõjas osalenud said (Vilde) raamatu kirjutamise ajal veel kirjapandavat mõjutada ja uut informatsiooni anda" (Lust 2003: 125).

${ }^{7}$ Oma käsitluses 1841. aastal toimunud Pühajärve „sõjast” osutab Hans Kruus hoiatavalt ning allikakriitiliselt sõna „sõda” tõlgendamise raskustele, kuna see näitab vastuhakku suuremana, kui see tegelikult oli. Isegi siis, kui kuulata seda, mida rahvasuu ütleb, väidab Kruus, et „sõda” ei tähendanud mitte kogu vastuhaku sündmustikku, vaid ainult selle karistavat peatükki (Kruus 1927: 14-15). 
kaotuste ning karistustega, pakuvad nad süžeena nii dramaatilisi, romantilisi, eepilisi kui ka traagilisi kujutusvõimalusi. Vilde romaanis „Mahtra sõda” on võimalik näha neid kõiki: romaanis on rohkesti dialoogi ehk „lavakõnet”; ülestõusu kronometreerimine annab lokaalsele sündmusele eepilise mõõtme; mässule osutatakse üldnimetusega „kurblugu” ehk „kurbmäng”. Need neli dimensiooni omakorda sulanduvad suuremaks tervikuks, mida Vilde Émile Zola eeskujul nimetab „sotsiaalseks" romaaniks. On huvitav tähele panna, et mahult haarab kaks päeva väldanud Mahtra sõja enda kronoloogiline ning eepiline käsitlus vaid poole romaanist (Vilde 1949: 321-442), täpsemalt raamatu teise osa teise poole. Vilde näitab Mahtra ülestõusu mitte kontrollimatu palanguna, vaid rahumeelsete sammude jadana: enne uuritakse uut talurahvaseadust kolmes kohalikus keeles (mille nimel käiakse nii Tallinnas, Juurus kui ka Kärus), peetakse talupoegade omavahelisi nõupidamisi, koordineeritakse passiivset vastupanu abiteole, lepitakse kokku mitte Habajale minna. Mässamine on viimane samm, eelmiste tegevuste nurjumise kulminatsioon.

„Mahtra”, viimane suurem talupoegade vastuhakk XIX sajandil, mida vaatamata rängalt traagilisele lõpule peetakse 1860. aastatel toimunud ulatuslikumate talupojareformide tõukeks, muutus rahvasuus sarnaste sündmuste üldnimetajaks, kuigi seda protsessi on võimatu täpselt jälgida. Juhan Kahki väitel sünnitas 2. juunil 1858 aset leidnud Mahtra „sõda” varsti pärast osavõtnute karistamist küünlapäeval 1859 Põhja-Eestis kobara kohalikke rahvamuistendeid, mis ringlesid suuliste mälestustega põimunult. Mööname siiski, et see rahvapärimus ei ole suuremahuline ja need muistendid ei levinud palju kaugemale kui sündmustest puudutatud mõisad Kosest Juuruni. Eestikeelsesse kirjasõnasse jõudis Mahtra sõda ikka Vilde romaaniga, mis ilmus esmalt järjejutuna poliitiliselt käremeelses päevalehes Teataja ning Mahtra sündmused kinnistas, võiks öelda, et isegi igavikustas. ${ }^{8}$

„Mahtra sõja” saamisloo erinevaid aspekte ning faase Villem Alttoa ning Herbert Salu käsitlustes on kõrvutanud ning sünteesinud Mall Jõgi, kes väidab, et „selge vihje kirjaniku mõtetes idanema hakkavale romaanile” leidub Vilde kahes 1894. aasta algupoole kirjutatud kirjas J. H. Vahtrikule (Jõgi 2007: 418-419). Ka Eduard Vilde jaoks oli Mahtra sõda süžeena mitte niivõrd eraldiseisev sündmus, kuivõrd sünekdohh kauakestnud teoorjusaegse ühiskondliku korra (koormiste, liikumisvabadus- ning abiellumispiirangute, kodukariõiguse, sh ihunuhtluse) ning selle vastu stiihiliselt plahvatavate talupojavastuhakkude kohta. Oma eessõnas „Kogutud teoste” sarjas ilmunud romaanile seletab Vilde selle „ehituslaadi”: „Kuigi ma neid sündmusi, mis oma jutustusele olen värvikaks t a g a s i n a ks [minu rõhutus $-T$. $K$.] valinud, nii asjalikult kui ajalooliselt õieti ja võimalikult täielikus raamis lugejale püüan silma ette tuua, on minu peasihiks siiski midagi muud: ma tahan oma romaanis tähendatud ajajärgust, teoorjuse lõpust Tallinnamaal, enese nõrka jõudu mööda ül di s t [autori rõhutus] pilti joonistada” (Vilde 1957: 269). Romaani edasise retseptsiooni kaudu muutus „mahtra” tagasihaaravalt kultuurilooliseks üldtähistajaks paljudele väiksematele ning suurematele talupoegade käärimistele eelnevatel aastakümnetel, haakudes ettevaatavalt, futur

${ }^{8}$ „Teose looming seisab ligidases ühenduses ajalehe „Teataja” asutamisega 1901. a. lõpul. Astudes uue radikaalse häälekandja toimetusstaapi, tundus mulle soovitavana, et lehe opositsiooniline, feodalismi ja oligarhia vastu sihitud ilming kohe alguses ka ,joone all” tuleks nähtavale - mõte, mida väljaandja ja peatoimetaja Konstantin Päts elavalt pooldas" (Vilde 1957: 268). 
antérieur'i võtmes veelgi suuremate rahutustega, mis lähitulevikus lahvatasid 1905. aasta revolutsioonis. Niisiis eesti proosakirjanduse napilt poolteist sajandit kestnud ajaloo mõõtkavas tuleks talupoegade mässu, selle hüpotekstilisust ja narratiivse poeetika vaatlemist kindlasti alustada Vilde „ajaloolikest” romaanidest (Tuglas 1909: 180), ${ }^{9}$ eriti tema ajaloolise triloogia esimesest köitest „Mahtra sõda”.

\section{Järjejuturomaan ja tema lugeja}

Nagu mitmed kirjandusloolased koos Vilde endaga on kinnitanud, oli romaani kirjutamine ajas küllalt lähedal 1858. aasta kevadel toimunud rahutustelainele, nii et elavate rahvamälestused sellest veel ringlesid (Alttoa 1973: 183). Tänapäeva keelepruugis „mälumaterjali” on romaanis märkimisväärselt palju, kohati on see otsene, äärtest karune, ilma stiili tasandava üleminekuta. Kas see on romaanipoeetika seisukohast hälve või strateegiline võte? Lugejat paneb mõtlema, kas Ants Veldi mälestuskäsikirjast tsiteeritud XVI peatükk romaani teise osa alguses ning pikemad ümberjutustused Hans Tertsiuse mälestustest ei ole mitte täited, mis võimaldasid autoril pisut hinge tõmmata, kallata otse allikast ilma uhkema poeetilise eesmärgita.

Vilde öine, hingeldav, ajalehe trükkimineku tundi trotsiv kirjutamistempo meenutab teisigi Euroopa autoreid: Charles Dickensit, Honoré de Balzaci, Émile Zolad, kes avaldasid oma mahukaid sotsiaalsest kriitikast laetud romaane esiteks ajalehtedes ning ajakirjades, kannustatuna leivavajadusest, ning alles hiljem raamatutena. „Mahtra sõja” esmalugejad olid ajalehelugejad, nende hulgas kaudlugejad, kellele ajalehte ette loeti või järjejutte suuliselt ümber jutustati. Romaani komponeerimine joonealuse järjejutuna seadis kirjutajaile ka mõningaid vormilisi piire. Köitmaks lugeja huvi ning toestamaks tema mälu tuli lühikestes jagudes seesmist narratiivset pinget ülal hoida, sündmustik sidusaks ja jälgitavaks teha ning anda nii tagasi- kui ka ettevaatavaid signaale, et lugeja ootaks põnevusega järge. Järjejutt nõudis ökonoomsust tegelaste iseloomustustes ning olustikukirjeldustes, mille jaoks kasutati pakse värve, meeldejäävaid kontraste ning raamistusi. Sotsiaalne romaan püüdis ärgitada lugejas nii paatost kui ka kriitilist meelt, veenda teda kujutatud olukorra ebaõigluses või rusuvuses ning motiveerida seda muutma või vähemalt ette kujutama teistsugust, paremat maailma.

Samaaegselt järjejutu peatükkide haldamisega tuli ehitada „suurt lugu”, mis tõuseks eepilisele või üldistavamale tasandile. „Kurbloole” pühendatud romaaniosale annab sidususe kronoloogiline järjestus ning daatumite nimetamine. Vilde suur lugu, eesti talupoegade ülestõusu lugu muutub aga Mahtra sõja rekonstruktsioonist korduvnähtuse analogiseerivaks mudeliks. Kahtlemata on järjejutuna avaldatud romaanil kalduvus kujuneda „lohisevaks”, hälbida terviklikkusest, mõnikord unustada ja maha pillata tegelasi või taustadetaile. ${ }^{10}$ „Suure loo” ehitamise käigus monteeris Vilde romaani seletavaid,

\footnotetext{
${ }^{9}$ Mõiste, mida Tuglas kasutas Vilde romaanide kohta. Vanemad eestikeelsed žanrinimetused ning nende tähendusareaalid sisaldavad sugestiivseid võimalusi ka tänapäevastele romaaniteoreetilistele arutlustele: $\mathrm{nt}$ ajalooromaan $v s$. ajalooline romaan.

${ }^{10}$ Raamatuks redigeerimine võimaldas Vildel hiljem mõningaid proportsioone ning detaile selgemaks ning ladusamaks kirjutada. Mall Jõgi (2007: 425-427) käsitleb lähemalt romaani algkäsikirja säilitamise ja leidmise lugu.
} 
tõestavaid ning ideoloogilisi telliskive, väljavõtteid Mahtra sõjast osa võtnud või seda pealt näinud inimeste käsikirjalistest mälestustest ning joonealuseid viiteid, seletamaks näiteks 1856. aasta talurahvaseadust kui dokumenti ning teoorjusaegse elumaailma detaile. Arvestades selgitavat materjali ning arhiivimaterjalide katkendeid, mille pookekohad on romaanis selgelt ning silumata nähtaval, on Mall Jõgi õigustatult nimetanud Vilde „Mahtra sõda” „dokumentaalromaaniks" (Jõgi 2007).

\section{Mahtra naised ja naiste Mahtra: Huntaugu Miina, talupojaperekond, seksuaalne vägivald}

Teoorjuseaegses rõhuvas sotsiaalpoliitilises süsteemis on mitu lüli, mida Vilde oma romaanis näitlikustab eesmärgiga paljastada süsteemi kui „masina” toimimist. Esiteks rendilepingud, mille raames Eestimaa talupojad 1819. aastal ilma maata „vabastati”. Mõisnik võis omavoliliselt talupoega ühelt maatükilt teisele paigutada või talupoega karistada kogu tema pere väljatõstmisega. „Mahtra sõjas” on Huntaugu, hiljem Ristmäe Mihkli perekonna suurema ning parema koha peale tõstmise hinnaks ühe teise talupoja väljatõstmine. Uuetoa saunas elav Päärn on vastupidi alandatud saunikust teomeheks oma surnuks pekstud isa vastalisuse tõttu, kellelt võeti mõisnikule vasturääkimise eest talukoht ja peremehe staatus ära; kuni romaani lõpuni ei ole ei vana ega noor parun Heidegg nõus „vastalise” pojale talukohta andma. Süsteemi teiste tunnuste hulka kuuluvad mitut liiki koormised, ka „Mahtra sõja” juhtumi jaoks võtmeline 1856. aasta talurahvaseaduses nimetamata jäänud abitegu ${ }^{11}$ (sõnnikuvedu, heinategu, rehepeks). Väiksematelegi töödistsipliinist hälbimistele järgnes jõhker ihunuhtlus mõisa politseivõimu suval: talupojal puudus reaalne õigus kohtusse kaebusi esitada. Lisaks oli talupoegade liikumisvabadus peaaegu täiesti piiratud (Peeter Olanderi öine retk Kärusse oli karistatav mitte ainult ässitamise, vaid pelgalt mõisapiiridest lahkumise pärast; sõnumitooja Miina Ermel Habajast eksis samuti, tulles Mahtra talupoegi hoiatama) ning abielusuhted mõisniku käsu ning keelu all.

Vilde võtab luubi alla ühe mõisnike võimu sageli mainimata jäetud või maha vaikitud aspekti: meelevaldse, sageli vägivaldse talunaiste ning talutütarde ahistamise, mille kohta „esimese öö õigus” on liiga mahe formuleering. ${ }^{12}$ Herbert Salu võrdleb seksuaalse vägivalla teema käsitlemist Vilde

${ }^{11}$ Romaanis kujutatakse ajalooliselt täpselt, et arusaamatused abiteo kehtivuse kohta tulenesid 1856. aasta talurahvaseaduse paragrahvidest 33 ja 127, mis jätsid abiteo otseselt mainimata. Kahk nendib, et probleeme oli ka seaduseteksti venekeelse originaali ning nii saksa- kui ka eestikeelsete tõlgete mitteklappivusega just nendes paragrahvides, kuid ka mujal. Romaanis kujutatakse tõlgendamispundart, mis tekib, kui talupojad üritavad seadust lähedalt lugeda, paluvad selle lugemisel abi nii saksa pastorilt, linnas elavalt eesti kaupmehelt kui ka vene õigeusu kiriku preestrilt, kes kõik on tõrksad talupoegi seaduse lugemise ning seletamisega aitama (Kahk 1958: 89).

${ }^{12}$ Ei ole üllatav, et Vilde jaoks oluline uurimismaterjal, anonüümne poleemiline essee „Der Ehste und sein Herr” (1861, autoriks tõenäoliselt Vassili Blagoveštšenski, e.k ilmunud 1959. aastal pealkirja all „Eestlane ja tema isand” P. Sillaotsa tõlkes) ei tee peaaegu ühtegi vihjet nais- ning meesteoorjade kohta käivate reeglite, koormiste ega tööde soolistele erinevusele, välja arvatud nais- ning meestöölise palkade võrdluses, mis on omakorda võetud 1853. aastal ilmunud teosest „Eestimaa rüütlimõisate nimestik koos mõnede statistiliste andmetega parun Reinhold Uexküllilt” (Der Ehste... 1861: 68-69). 
triloogia esimeses kahes osas, „Mahtra sõda” ja „Kui Anija mehed Tallinnas käisid”: „Suurmaapidajate võimutäiuse kujutamisel on romaanis [„Kui Anija mehed Tallinnas käisid" - T. K.] pearõhk asetatud mõisniku ja talunaise seksuaalvahekorra kirjeldamisele. Kui eelmises teoses, „Mahtra sõjas”, Huntaugu Miinat ähvardanud vägistamine opman Vinteri poolt lõppes nurjumisega, siis andis see episood tegelikkusest vildaku pildi, mis vajas korrigeerimist uues romaanis. Triloogia teise osa süžee ongi peamiselt ehitatud aadli „esimese öö õigusele" - peategelaste saatus oleneb täiel määral mõisnike sugulisest vägivallast talunaiste suhtes" (Salu 1981: 60).

Romaanis „Mahtra sõda” illustreerib Huntaugu Mihkli „kaup” ehk täpsemalt oma tütre Miina kaubitsemine esiteks Kupja-Pritsule, hiljem opman Vinterile, kui õhukese niidi küljes terve perekonna heaolu ripub: kui Mihkel tingimusi ei täida ja Miinat opmani juurde teenijaks ei saada, võetakse talt seegi talukoht ära, mis tal praegu on. Emad kartsid tütreid mõisahäärberisse teenijateks saata, kuna nii sattusid nood ärakasutamise ohtu paruni ja tema meessoost perekonnaliikmete poolt; rasedaks jäädes oleks neid paari parseldatud mõisniku poolt meelevaldselt valitud talupojaga, kes tagajärjed legaliseeriks. Seksuaalse vägivalla rakendamine, et talupoegade naisperet alandada ning häbistada, moonutas talupojaperekonda, avaldudes nii otsese sekkumisena pere siseellu kui ka kaudsemalt, patriarhaalse võimu jagamisena. Pereisa kui mõisniku analoog võis võimutseda, tarvitada verbaalset ning füüsilist perevägivalda, kuid kuna ta oli mõisniku suhtes sundolukorras, oli see jäljendav peremehetsemine hale mäng, mis pigem rüüstas perekonnapea mehetunnet ning väärikust (Stoler 2002: 180-181).

Perekonna füüsiline elamispind ja heaolu sõltus sageli noorte tüdrukute vaikivast alistumisest nii väikestele ahistamisaktidele, vägistamisele kui ka jätkuvale pruukimisele, samas aga nõuti neilt oma vooruse vaprat kaitsmist. Miinatki manitseti kodus, kui ta kurtis opman Vinteri lähenemiskatsete üle, et tuleb vastu pidada ja välja kannatada (ptk 18, lk 247). Samas küsib temalt lakooniliselt Päärna ema (Uuetoa saunaema), kas tal opmani köögis siis ahjuroopi käepärast pole. Mõisas „puhastel töökohtadel” teenivate külatüdrukute kiusamine (Päärna õde Mai), seksuaalne ahistamine (Kulbi Kai) ning vägistamine ei ole isoleeritud ega harv nähtus, vaid osa süsteemist, mis hoidis talupoegi vaos. Nagu opman Vinteri vägistamiskatse järgse valesüüdistuse kaudu ilmneb, ei olnud tüdrukutel endil ega nende perekondadel mingit juriidilist kaitset seksuaalse vägivalla eest. Et sundija väärkäitumist varjata või õigustada, peksti julmalt hoopis ohvrit ning tema kaitsjat, meest, kes ta vägistamisest päästis. Tüdruku psühholoogiline karistus on rängem, mitte ainult Kupja-Pritsu ning opmani sadoerootilise naudingu tõttu peksu ajal, vaid laimu ning maine mustamise tõttu. „Mahtra sõja” süžeed arendades asetab Vilde suurendusklaasi alla koloniaalvägivalla, näidates selle toimimist perekonna kui pisikese mudeli sees. Huntaugu perekond koosneb käskivast, oma võimuga uhkeldavast isast, mõõdukast, malbest, kuid terasest perenaisest ja meelekindlast ning „mässulisest” noorimast peretütrest Miinast. Vanem tütar Mari on juba mõnda aastat kolmepäevatalu peremehe abikaasa. Miina perekonna lugu on selgelt välja joonistatud näide sellest, kuidas naiste ellujäämisstrateegiad erinevad igas elujärgus meeste omadest. Tütar on elav vallasvara, millega saab kaubelda perekonna heaolu nimel, kas negatiivselt (hullemate tagajärgede vältimiseks) või positiivselt (kas või väga piiratud sot- 
siaalse mobiilsuse nimel). Samas kehtib vallaliste naiste kohta külaühiskonna topeltstandard, mis juba ilmneb romaani alguses öise rehepeksu ajal, kui Kupja-Prits Kulbi Kaie näkku lööb ning Päärn takistab tema edasi peksmist. Kulbi Kai on lapsega tüdruk, kellele vaadatakse külas teatud määral võõriti. Miina ja Päärna esimese arusaamatuse põhjustab Kupja-Pritsu manipuleerimine kuulujuttudega Päärna eestkostest Kaiele, mis olevat midagi enamat, riivates Miina usaldust. Kupja-Pritsu kuulujutud on sünge näide sotsiaalsest kontrollist külaühiskonnas, mis on seda mürgisem, et kuulujuttude levitaja on „sundija”, omade rõhuja omade seast.

Kupja-Pritsu esmane pakkumine Huntaugu Miinat kosida sisaldab meelitavat ettepanekut kindlustada Huntaugu perele parem talukoht, kuhu Kupja-Prits ise kavatseb hiljem koduväiks tulla. Pritsuga abiellumine on Miinale algusest peale vastumeelne. ${ }^{13}$ Miina ema Viiu näitab esialgu kaastundlikku suhtumist ning poolehoidu oma tütrele. Samas rakendab ta oma elutarkust ning abielukogemust, et pehmendada pereisa kärkimist ja maandada pereliikmete ülekeevaid emotsioone.

Huntaugu Mihkli põhjendusel, miks ta Miina kallimat Päärna väimehena valeks valikuks peab, on oma sisemine loogika: see, kes saksa lööb, see, kellel on kalduvus vägivaldsele käitumisele võimukandjate vastu, tõenäoliselt paneb toime ka perevägivalda. Küll aga on Mihkli hinnang pealiskaudne, isegi klišeelik. Jutustaja poolt on see eesmärgipärane ja signaliseerib lugejale, et ka teistes olukordades ajendub Mihkli käitumine kuulekast, omakasupüüdlikust suhtumisest mõisavõimu, viies vajadusel ka silmakirjalikkuse ning lömitamiseni.

Kosjade edasilükkamine on vaid ajutine kompromiss. Kupja-Pritsu pakutud „kaup” nõuab „tüdrukuga asja tahedaks tegemist” vanemate poolt. Sellel pingelisel ajal alistub Viiu olgu siis hirmust või parema elujärje peibutusest oma mehe plaanile survestada Miinat Pritsu kosje vastu võtma. Ta põhjendab oma meelemuutust terve pere majandusliku heaoluga: „Ema ja tütar olid isekeskes asjast kõnelnud, ilma mingisugusele abitõotavale otsusele jõudmata. Miina teadis ainult seda, et ta Pritsule minna ei taha, ja ema ainult seda, et tütar õnnetu oleks, kui ta sellele mehele läheks. Aga seal sündis emaga nädala jooksul ime. Ta hakkas võimalikuks pidama, et Miina Pritsule läheb, ning võimalikuks pidama, et ta oma saatusega viimaks üsna rahul on. Suurem ja parem koht, rohkem loomi, rohkem vilja, rohkem piima, rohkem linu ja villu; Mihkel mõisas viinaperemees, tütar mõisas kupja naine. Tuleb mõne aja pärast isamajja tagasi: ega ta tühjalt tule" (ptk 6, lk 91). Järgnevas siirdkõnelises passuses loeb perenaine üles ettekäänete ning eneseõigustuste jada, milles Pritsu iseloomuvead tunduvad vähem olulised kui enne. Südamearmastus ei ole iseseisev väärtus; parimal juhul tasandab see pinda laste muretsemiseks. Ema pooltevahetamine ja oma mehele allaandmine Miina edasise saatuse suhtes meenutab Pearu naise mõtisklust vägivalla talumisest abielus $\mathrm{A}$. $\mathrm{H}$. Tammsaare „Tõe ja õiguse” esimese köite teises peatükis; abiellumise hüve oli Pearu naise silmis tagasihoidlik tõus sotsiaalsel positsioonil. „Talupojamõis-

\footnotetext{
${ }^{13}$ Kõige selgemalt, ausamalt ning otsesemalt väljendab Miina oma vastumeelsust KupjaPritsule alles viimases instantsis, opman Vinteri köögis: „Miina vaatas kannatlik-tüdinenud ilmel pliidi all pragisevasse tulle, mille punakas paiste ta näol heitles. „Sa tead jo, Prits, et ma mitte ei taha,” kostis siis pehme, sõbraliku häälega. „Meie ei ole teineteisele loodud. Minu veri ei tõmba sinu poole, ma tunnen seda selgesti, ja sina peaksid sest kord aru soama"' (ptk 12, lk 172). Opmani ja Pritsu rivaliteedis Miina üle väljenduvad ülemkihi stereotüübid talupoegade, eriti nende naispere seksuaalsest lodevusest ehk promiskuiteedist.
} 
tuse" feminiinses võtmes oli suur osakaal kompromissil ning kannatlikkusel, ükskõik kui jõhkra, vägivaldse või halva iseloomuga mehega harjumisel. Oluline oli kas või pisike nihe ülespoole külaühiskonna hierarhias, saunanaisest perenaiseks saamine.

Jutustaja nimetab Viiu meelemuutust irooniliselt „imeks”. Vilde ei anna oma tegelastele psühholoogilist sügavust nende siseilma kirjeldades, vaid valgustab neid dialoogide kaudu, kohati ka iseloomu summeerivate vormelitega. Pärast Pärtli Jaani ja peatse kosilase Kupja-Pritsu külaskäiku üritab Miina oma emaga avameelselt rääkida, kuid tulemusteta. Romantilise kangelannana tajub Miina oma piiramisrõngast teravalt ning võtab mässulise hoiaku: „See oli pikk, pikk vaade, mille Miina nüüd ema peale heitis. See oli merehädalise vaade, kelle kätest viimane laevakild libisenud.... Siis aga süttis Miina pruunis silmas ere lõke, ta surus hambad kokku, lõi käed puusa ja hakkas äkki naerma. Mida ta naeris, jäi emale mõistatuseks" (lk 95). Patriarhaalses talupojaperekonnas on Viiu meelemuutus kui mitte oma tütre reetmine, siis vähemalt ema-tütre solidaarsuse murdmine, millisena Miina seda ka tõlgendab.

Miina resoluutne naer viib tegudeni: ta häbistab oma vanemaid sellega, et põgeneb Pritsu formaalse kosjavisiidi eest vanema õe Mari juurde. Jutustaja ei unusta märkimast, et Mari on abielu kaudu paremal järjel kui isakodus: ta läks mehele kolmepäevatallu. Kui Miina kaotusvalu ning kosjahäbi on perekonnas juba mõned päevad põetud, saabub Mari teatama, et Miina on põgenenud tema juurde ning et ka tema ise oleks Miina asemel põgenenud. Mari arvab oma seniste abielunaisekogemustega, et parema talu peale saamine on tühine; pereõnne tagab armastus. Mari seisukoht tasandab teatud määral Miina käitumise romantilist mässuvaimu, jõudes teist teed pidi samale tulemusele.

Sõlm Miina kui „elava vallasvara” ümber tõmbub kokku Kupja-Pritsu järgmises, süngemas ning konspiratiivses kosjaplaanis, mil ta veenab opman Vinterit, et too nõuaks Miina endale mõisa tüdrukuks. Prits teeb pakkumise magusamaks, kinnitades Huntaugu Mihklile, et oma tütart opmani juurde saates kindlustab ta endale uue talukoha ning selle üsna peatselt ka kätte saab. Naistööjõud on kergesti asendatav: kui Huntaugu Mihkel kardab Miina kui pere „ainsa palgata töölise” töökätest ilma jäämist, vastab Prits, et võtku ta teenija asemele (ptk 12, lk 168-169). Kuna see lahendus on Mihklile majanduslikult kahjulik, nõuab ta Miina kohese läkitamise eest uue koha juba jüripäevaks. Kahe mehe (kupja ning opmani) kokkuleppel kehtestatud järelevalve isoleeriks Miina tema perekonnaringist ning sellega kaasnevast kaitsest, andes ka võimaluse pikkamööda psühholoogiliselt õõnestada kangekaelset vastupanu Pritsu kosjadele. Mihkli kindlus uue talukoha saamises kaalub üle Viiu hirmud tütre ahistamise ees: opman Vinteri jooma- ning naistehimust on terve küla teadlik. Miina alandlik alistumine uuele pakkumisele on strateegiline edasilükkamine tütreliku alandlikkuse katte all. Miina mõistab, et kui ta keelduks Vinteri juurde teenijaks minemast, tõstetaks Huntaugu pere ka sellest talukohast välja, kus nad on seni elanud. Siingi näeme Miina tegelaskuju ülesehitust meele ja mõistuse tasakaalus: Miinat ei juhi vaid üksainus romantiline väärtus ehk südamearmastus, vaid kaine arusaamine perekonna haprast seisust ning manipuleeritavusest.

„Mahtra sõjas” kujutatud sootsiumis ei näidata mehi ja naisi eraldatuna oma tegevussfääridesse, vaid toimimas suhtlusvõrkudes ning hierarhiates nii 
perekonna- kui ka külasiseselt. ${ }^{14}$ Sarnaselt valgustatakse läbi sugudevahelised suhted mõisas. Ka on Vilde jutustaja asjaliku põhjalikkusega seletanud koormiste „naiste töö” aspekti. Üheksandas peatükis kirjeldatakse naiste teotöid peeruvalguses: „Leelõukal saadab töötav kodakond oma pika üksluise talve mööda. Perenaine, tüdruk, tütar, kõik ketravad - osalt mõisa, osalt endale. Ahjunurgas või peerujalal põleb üks peerg teise järel söeks, lapsed kohendavad ja uuendavad neid järjest - see on nende amet, nende osa üldisest tööst. Tüdruk, kes mõisa ketrab, pingutab ja sihib piinliku hoolega koonla ja värtna vahel jooksvat lõnga, et ta peeneks saaks kui hing ja et talle ainust lipsukest sisse ei jääks. Sest kui viht väikesest rõngast või sõrmusest läbi ei lähe, siis on proual tüli lahti” (ptk 9, lk 127). Töökorralduse detailid antakse läbi jutustaja silmade, mis vaatavad kordamööda sisse mitmest aknast. Stseeni raamistusest selgub, et kirjeldatu jääb väljapoole Juliette Marchandi vaatevälja ning kõndimispiirkonda, talupoegade naisperet näeb ta vaid siis, kui nood tulevad oma töömaterjale mõisaproua käest kätte saama. Soolist solidaarsust ei saaks seisuste vahe tõttu tekkida. Selleks on Juliette, kes kuulub teeniva rahva kõrgeimasse kihti, liiga kättesaamatu.

Mässu eelõhtul, kui Juuru hingekarjane Berg naised ja lapsed kõrtsi manitsuskõnet kuulama kutsub, toob jutustaja lavale ka naismässaja, kes katkestab „haleda meeleolu”: „Keegi suur, tugev, kuivetu naine koltunud näoga, millele töö ja mure sügavad vaod künnud, astus piitade vahele ja hüüdis rämeda mehehäälega kõrtsi sisse: „Kui mehed ei päri õigust taga, kes siis peab pärima? Kas naised ja lapsed?"” (ptk 23, lk 329). Sellele vahelehüüdele järgneb lause, mis väljendab pastori arvamust mehe ja naise positsioonist: „Kuid õpetajal näis olevat südamest kahju, et ta lahingu peab kaotama, pealegi ühe vana naise mõjul."

Mahtra sõja rängad tagajärjed ülestõusnud talupoegade peredele on kokku võetud romaani eelviimases peatükis, pärast karistusstseeni Mahtra verepõllul. Siin näeme ka Vilde selektsioonistrateegia lõpptulemusi, kuna karistusstseenis figureerivad esiplaanil kohtuprotokollides nimetatud juhid. Romaanis mainitakse oma õige nimega Mahtra mõisa talupoega Ado Andreid, kelle nimi on esimene Mahtra kohtuotsuses (Reinthal 1923: 116). Arvestades Andrei eelmisi kokkupuuteid seadusega - süüdistus tapmises ning karistus varguse eest -, on tema karistus Mahtra sõjast osavõtmise eest üks julmemaid. Kuigi võiks arvata, et kohtuprotokolle lugenud Vildele ka Andrei perekonna edasine saatus silma jäi, ei leia Ado naise Anu elukäik romaanis käsitlemist, vaid jääb jutustusest välja. Ehk tuleneb see väljajätt ka ettenägelikkusest tsensuuri osas. Johannes Reinthali lühimonograafias võetakse kohtuprotokollide najal kokku Anu Andrei raske saatus pärast abikaasa Siberisse saatmist: ta jäi ilma ka viimasest riidest ja lõngast, mis oli temalt Mahtra valitseja Rosenbergi poolt ebaõiglaselt sisse nõutud mehe „võlgade” tasuks (Reinthal 1923: 146). Valitseja Rosenbergi ei kõrvaldatud ning Mahtra ajaloolistes allikates mõistagi puudus Juliette Marchand, täisfiktsionaalne kõrvaltegelane ning valgustuslik moraalne pedagoog. Reinthali monograafias joonistuvad tänapäeva mõistes mikroajalooliselt välja arhiivimaterjali kätketud rohked latentsed lood inimsaatusest - Mahtra sõja kui suure sündmuse mosaiikkivid.

\footnotetext{
${ }^{14}$ Natalie Zemon Davis (1996: 103) kasutab fraasi „sugudevahelised sotsiaalsed suhted”, hoiatades, et meeste ja naiste eraldi käsitlemine ajalookirjutuses on eksitav, kuna see jätab välja nende dünaamilise omavahelise suhtlemise sotsiaalses protsessis.
} 


\section{„Prantsuse mamsel”}

Kui Miina saadetakse pärast julma peksu koju tagasi, ei vaiki ta. Lugu liiga karmist karistusest liigub teenijate Maie ja Tohvri kaudu mõisa, jõudes Juliette Marchandi kõrvu. Juliette’i kanda on põhjalikult läbimõtestatud valgustusideedele tuginev kriitika kolonialismi olemusliku, oma eripärase raskusega „õrnemat sugu” rõhuva vägivaldsuse suunas. See mõistab hukka patriarhaadi kahekordistuva rolli nii mõisas kui ka talutares. Šveitsi prantsuskeelsest piirkonnast pärit Juliette’i nimetatakse siirdekõnelises passuses „prantsuse mamsliks", kui Juliette vana mõisniku ja mõisaproua suureks kergenduseks Herbert von Heideggi esimese kosjakatse tagasi lükkab: „Nüüd aga hüüdis üks jumalale tänu ja teine kiitis, et tüdruk on targem kui poiss, ja mõlemal oli tundmus, kui oleksid nad suurest hädaohust pääsenud! See p r a n t s u s e m a m s li k e [minu rõhutus $-T$. $K$.] seisis ju nii madalal, et ta kõige väetimatki Heideggi ei suutnud teotada, ja nii madalal seisis ta, et ta tegi palga eest tööd..." (ptk 22, lk 296). ${ }^{15}$

Juliette'i kujutatakse romaanis ilusa, eksootilise ning võõrana, mis suurendab tema külgetõmbejõudu noorele parunile. Vaatamata tema rangele, mõistuslikule enesedistsipliinile lubab jutustaja samas 22. peatükis Juliette'ile mõisaprouafantaasia, milles on tugev laeng meelelisust, kuid ka moraalne kirg mõisa tingimusi inimlikumaks muuta: „Oli ju Juliette naise vaimuerkusega palju varemini jälile jõudnud, et teda siin majas midagi ootab, mis ühtegi noort rinda sarnasel juhul ei jäta erutamata [---] Siin aga ei puudunud ükski tingimus. Juliette'i ees seisis noor, nägus, andekas, ausameelne mees, kellega ta ruttu sõbrunenud ja kelle seltsis ta nautis seda sooja lõbu ja mõnu, mida sünnitab vastastikune meeldivus. Mis ime siis, et neiu põues midagi lõi tärkama - salaja, vastu tahtmist. [---] ... ta peast lendasid terved suured tulevikupildid läbi, mille keskpaigas seisid koos ikka jälle Herbert ja ta ise. Ta oli endale sedagi kord välja maalinud - salaja, vargsi muidugi -, kuidas ta oma osa mängiks Vaitla mõisa prouana..." (lk 297). On huvitav, et see õilis fantaasia lõpeb etnilise stereotüübiga, justkui ei oleks see enam Juliette'i, vaid mõisaperemehe ja tema abikaasa siirdekõne: „,- ja seda kõik on see väike must prantslanna aidanud korda saata!" (lk 297).

Mahtra ülestõusu maskuliinse süžeeliini taustal saavutab Juliette opman Vinteri seksuaalse vägivalla avaliku hukkamõistu ning opmani tagasiastumise. Ta suudab noorparunit veenda oma mõtteraamidest välja astuma, et teha tegelik ja otsustav samm. See mõjub rüütelliku kingitusena, kuigi Juliette loobub lõplikult armuloost Herbertiga. Romaani 29. peatükki täidab mõlema romantilise liini dénouement. Miina vooruslik maine taastub ning tema vanemate talu ei võeta kättemaksuna ära. Nagu lugejale on juba varem mõista antud, lõpeb Miina ja Päärna armulugu õnnelikult vaatamata Päärna maksimalismile, mille juureks on temasse isa mõrva kaudu varakult sisse istutatud viha ning mille moraalselt tempereerivaks jõuks on Miina, kes jookseb Vaitlast Mahtrasse, et Päärn ja Jüri „sõjast” koju kutsuda. Argument, mis mõle-

${ }^{15}$ Et mõisnik Heidegg ja tema proua Juliette'i ekslikult prantslannaks pidasid, on näha selle atributsiooni kolmekordset kasutamist romaani 22. peatükis. Nende silmis määras sotsiaalse positsiooni seisuslik, mitte etniline ega geograafiline päritolu. Täpsemaks kui „prantslanna” ei olnud vaja koduõpetajanna iseloomustamisel minna, eriti kuna temas nähti ohtu noorparuni „äravõrgutajana”, temas seisusele sobimatu partii idee tekitajana. 
male tulipeale veenvalt mõjub, sundides neid oma mõisast varastatud asju põõsasse heitma ning koju tagasi pöörduma, on meeste perekondlik kohus: mõlemad mehed on oma eakate emade toitjad. Ilma Juliette'i vaheleastumise ning Herbert Heideggi lootusetu, kuid rüütelliku armastuseta Juliette'i vastu oleks Päärna lugu arvatavasti lõppenud surnukspeksmisega.

Nagu Walter Scotti romantismiaegsetes ajaloolistes romaanides, kujutatakse „Mahtra sõjas” väärtussüsteemi nüansseerituna, läbi rohkete kõrvaltegelaste eluvaadete, mis on täpselt kadreeritud; samale väärtussüsteemile põhineb ka peategelaste Miina ja Päärna romantiline südameliit. Seisustevahelised liidud, näiteks liit Juliette Marchandi (vaesunud põlisaadli tütre) ja välismaal avardatud silmaringiga noorparun Herbert von Heideggi vahel on luhtumisele määratud nii noorparuni perekonna ületamatu hukkamõistu kui ka mentaliteetide, ilmavaadete ning väärtussüsteemide konflikti tõttu. Juliette esindab südameharidust ning moraalset mõtlemist, millest mõisas on vajaka ning mis tekitab põhimõttelise konflikti tema rollis parun Heideggi laste guvernandina. Juliette'i „vagune ja tumm” abielu koduõpetaja, iroonilise nimega Gottfried Lustigiga, kes ei teeks umbrohulegi liiga, on mitte ainult Juliette'i südamearmastuse isiklik ohver, vaid tema selge mõistuse vili. Kuigi romaanis on mitmel moel paljastatud koloniaalpatriarhaadi koostiselemendid, häiritakse selle „masina” toimimist ühe väikese erandiga. Uuetoa Jüri väljavalitu, toatüdruk Mari strateegilised võtted oma armastuse, isikliku õnne ning seksuaalsuse hoidmiseks toimivad tänu noorte naiste vahelisele seisusteülesele solidaarsusele, mis tänu Juliette'ile toob ka olulise läbimurde tavavägivalla toimimises.

\section{Milline ajalooline romaan? Järelelud}

Ann Rigney on väitnud, et ajaloolist romaani võib nimetada „iluvigadega” ehk „ebatäiuslikeks ajalugudeks” (Rigney 2001). Ajalooromaani „ajaloolise ebatäiuslikkuse hüpotees" tahab püstitada kiriku keset küla: tähendusrikast diskursust mineviku kohta loovad nii ajaloolased, kirjanikud, filmitegijad kui ka kunstnikud. Selline külalislahke inklusiivsus paraku siiski ei rahusta rangemate standarditega ajaloolasi ega väldi ajaloolaste ja ajalooromaanikirjanike ägedaid ning kroonilisi tülisid minevikudiskursuse tähenduslikkuse ning tähendusloome protsesside üle. Rigney nimetatud kolm strateegiat (selekteerimine, transformeerimine, lisamine), mis tuginevad väitele, et ajalooline romaan on möödapääsmatult hübriidne vorm, võimaldavad romaani komponeerimisele palju lähemale jõuda ning mõista tegelaste kooslusest tuletatava sootsiumi toimimisreegleid. Vilde „Mahtra sõja” tegelaskonna analüüsimine sellest aspektist peab hetkel paraku jääma teist võimalust ootama.

Marek Tamm on väitnud, et Jüriöö ülestõus, Mahtra sõda ning Võnnu lahing moodustavad ajalooteadvuses rahvusliku metanarratiivi, mis on loodud eelkõige kirjanduse kaudu; seega olevat Mahtra sõda „suure vabadusvõitluse” jätk (Tamm 1998) ning keskne lüli. Kirjandusloo historiograafia makrotasandil võib see väide õige olla, kuigi nii selle deklaratiivsus kui ka üldistusaste on nii suured, et kõik paistabki öeldud olevat. Nii see siiski ei ole, kuna väite õigsust peaks toetama vähemalt empiiriline retseptsioonilugu, mis on suurel määral kirjutamata: kes (ja millal) neid rahvuslikku metanarratiivi moodustavaid teoseid luges? Täpsemalt, kuna noort lugejat kujundab - vähemalt pas- 
siivselt - kooli kirjandusõpetus, siis tuleks küsida: kas ning millal need teosed (Bornhöhe „Tasuja”, Vilde „Mahtra sõda”) võeti kohustuslikku koolikirjandusse? Kuidas neid koolitundides tõlgendati, on teine küsimus, millele nii hästi ligi ei pääse. Kuid siin tekivad juba järgmised kõhklused seoses Marek Tamme rahvusliku metanarratiivi vähese diferentseeritusega: Vilde teostest võeti „koolitarviduseks” 1928. aastal vabrikutööliste teemaline „Raudsed käed” ning „Külmale maale”, järgnevalt „Mahtra sõda” ning „Kui Anija mehed Tallinnas käisid" (Vilde 1957: 258, 261, 268, 273). Vilde ajaloolises triloogias esile toodud viis põimunud topost - talupoegade vastuhakud, linnainimeste suhtumised kehtivasse agraarolukorda (linna ja maa suhted), nõrk hariduslik põhi, lahkusu kaasakiskuvus ning väljaränne - on märksa komplekssem, paradoksaalsem „pundar” kui Mahtra sõja vastupanulisuse topos üksinda. Vilde triloogia ideoloogiline ning ka pedagoogiline eesmärk oli tuua lugeja teadvusesse mitte ainult „sõja” kurbmängu, võitlemist, vaid ka teisi ilminguid ning nähtusi, mida kehtiv agraarolukord ning seda reguleeriv seisus- ning seaduslik kord põhjustasid. Lugedes koolis lisaks „Mahtra sõjale” Vilde jutustusi ja romaane „Raudsed käed” ja „Külmale maale”, sai kooliõpilane paljuski nüansseerituma pildi eesti rahva erinevate kihtide, linna- ja maaühiskonna kuuluvusest suurde ning kirjusse narratiivi, kui seda pakub heroiseeriva vabadusvõitluse monumentaalne sillakaar. Teisisõnu, Tamme visandatud metanarratiiv jätab umbselt rõhuva olukorra ning süte all küdeva vabaduspüüde mitmed aspektid allasurutud mõisteina varjule. Omaette iroonia on ka selles, et üks rahvusliku narratiivi hõlma all peidus olevatest lahendustest, mida tänapäevalgi „ebarahvuslikuks teoks” peetakse, nimelt väljaränne, on vabas Eestis ülimalt aktuaalne.

On selge, et ilma ligipääsuta suulistele ja kirjalikele allikatele - nii rahvamälestustele, tunnistajate ning osalejate kirjapanekutele kui ka Mahtra ülestõusu ametlikele protokollidele kubermanguarhiivides, mis Vildele avati eriloal - ei oleks Vilde romaan saavutanud ei oma krobelist ehedust ega didaktilist jõudu. Vilde triloogia on omas ajas kompleksne nähtus, kuna romaani kontekstuaalsed virvendused aitasid ajalehelugejate lugemiselamuste kaudu kujundada ka ärevaid 1905. aasta revolutsiooni eelseid meeleolusid ning meelsusi. Nii eestikeelse ajaloolise romaani alustekstina kui ka eepilise mustrina on „Mahtra sõda” mõjutanud 1905.-1906. aasta revolutsiooni sündmuste üleskirjutusi nii ilu- kui ka mälestuskirjanduses. Selle hüpoteesi tõestamine nõuab aga suurt tööd ulatusliku allikmaterjaliga ning ei tarvitsegi anda tagajärgi ehk „saaki” otseste viidete ega vihjete kujul. Pigem võivad uurijale silma torgata hoiakud, meeleolud, tõlgendusmustrid, korduvad fraasid, mis osutavad kaudsetele paralleelidele „Mahtra sõjas” väljendatud meelsusega ning mille juured on kirjutaja lugemiskogemuses. Kui romaani kirjutamine sai kasu Mahtra sõjast osavõtjate kirjalikest ning suulistest mälestustest, siis oma ilmumisele järgnevas „lähitulevikus” ulatab romaan kas või sümboolselt käe revolutsioonist osavõtjate nägemustele ning ootustele.

Kuuldud ja loetud lugude paljususest on Vilde „Mahtra sõtta” selekteerinud nii juhtumeid kui tegelasi, mis kokku annavad täiusliku pildi sootsiumi kihtidest, seda mitte ainult massistseenides, nagu rehepeks ja mäss, vaid ka küla ja mõisa vahel kulgevate lugude ja kuulujuttude võrgus ning kirjelduses Ants Tertsiuse osavalt välja mõõdetud sammudest uue talurahvaseaduse mõistmisel, sellele ratsionaalsel alusel vastandumisel, abiteost hälbimisel 
ning teekonnal Kärusse. On ka huvitav tähele panna, et Vilde triloogias kujutatud aega ning Tammsaare „Tõe ja õiguse” algust, mille teose esimene lause täpselt ära märgib (eelmise sajandi viimase veerandi alguses, seega 1875), eraldab vaid 17 aastat. Et Tammsaare päriseksostetud talu peremehe elu hajaküla raamistikus sisaldab vaid ärkamisaja sumbunud järelkajasid, on omaette küsimus. Küll aga jääb ärkamisaeg oma vaimustuste ning vihadega Vilde „ajaloolise triloogia” ning Tammsaare hoogustuva linnastumisaegse agraarelu vahele, justkui oleks see asetatud sulgudesse.

Kui Vilde käsitlus koloniaalvägivalla soolistest aspektidest teeb Mahtra sõja kui topose seesmiselt heterogeenseks, siis milline on Mahtra järelelu kirjanduses? Aino Kallase jutustuses „Bernhard Riives” sisaldub mässu-teksti rahvuslik valulisus Bernhard Riivese dialektilises kujus ning tema dilemmas orjaliku alandlikkuse ja vaba mehe surma vahel, kui ta 1905 . aasta revolutsioonile järgnenud karistussalkade ees valib peksu asemel mahalaskmise. Kallas aga ei too mässu ja mässulisi massistseenina lavale. Teiseks oluliseks mässupildiks eesti ajaloolises romaanis on Jaan Krossi „Kolme katku vahel” II köite süžeeline dominant, 1560. aastal toimunud Koluvere mäss, mille ülekanne romaanimõõtmesse ei ole niivõrd suurendus lakoonilisest lõigust Balthasar Russowi „Liivimaa kroonikas” kui osa romaanist võrsuva fiktsionaalse kroonika metahistoorilisest selgroost. Russowi-romaanis väljapakutud mässu koodid sisaldavad nii veendunud ning kaalukat sõtta minevat talupoega, meeleheitliku bravuuriga surma sööstvat sõdijat kui ka mässu sündmuste pealtvaatajat, kes lõpuks oma käsi ei määri. Nimelt eksib Russowi tegelane, kelle „kohalolu” mässu kurbmängu stseenides on algusest peale tinglik ning unenäoline, õigel ehk võimalikult saatuslikul hetkel teelt kõrvale (buduaari). Päev hiljem kappab ta Koluvere all metsa, jättes vaid jälgi mällu või fantaasiasse, õnneks aga mitte plekke sõrmedele.

Vilde ja Krossi vahel laiub maastik, mil kirjutati, avaldati, hiljem lausa telliti teistsuguseid ajaloolisi romaane, ka neid, mis rajanesid imaginaarselt täiuslikuks konstrueeritud heroilistel etappidel eesti rahva ajaloos, Sigtuna vallutamine nende hulgas. Mahtra-tekst, kas või oma minevikulise läheduse tõttu (nagu seda intervalli on manamisi sõnastanud Ene Mihkelson oma romaani „Nime vaev” alguses) on värvitud higi, vere ja häbi porise seguga. Aprillis 1988 toimunud Tartu muinsuskaitsepäevade meeleavaldusi vaadates kuuleb Mihkelsoni romaani jutustaja ühe naise hüüet, kes rahvahulgas visalt ettepoole tungib: „Ma olen Mahtra sõja veteraan!” (Mihkelson 1994: 5.) Teadliku lugeja jaoks on selle anonüümseks jääva naise hõise kas huvitav anakronism (kuna 1988. aastal on võimatu, et ükski Mahtra sõja veteran enam elus oleks ning naise hüüe murrab tõenäolisuse piire) või siis Marek Tamme metanarratiiviga sarnane liigendus: sama sillakaar ühendab muistset vabadusvõitlust, talupojaülestõuse (Pühajärvel, Mahtras), Vabadussõda ning laulva revolutsiooni avatakte. Anakronismi hüpotees on hoopis ergutavam kui metanarratiiv ise: pigem osutab anakronism metanarratiivi konstrueeritusele ning asetab selle iroonilisse valgusse, mistõttu ilmneb metanarratiivi ülilihtsustus ning selle varju jäävad paradoksaalsused.

On korduvalt küsitud, enamasti skepsise või kahetsusega: miks kirjandus „teeb” rahvale ajalugu? Imaginaarne ehedus, patriootilise paatose äratamine, millega seletatakse ajalooromaani toimet rahva ajalooteadvusele, võivad tuua pedagoogilist kasu, kui romaane loevad õigel ajal õiged inimesed. Sama oluli- 
ne, kui mitte olulisem on professionaalsetest ajaloolastest koosneva lugejaskonna kriitika ning hoiatused anakronismide, vigade või „kraavikaldumiste” eest. Ehk ei olegi nii lihtne nentida, et rahvusliku ajalooteadvuse kujundamisel on kirjanikud olnud peaosas ning ajaloolaste ülesandeks on jäänud „käibiva metanarratiivi teaduslik lihvimine, allikate ja autoriteetidega toestamine" (Tamm 1998: 401). Lisaks avameelsele dialoogile erinevatel tasanditel „minevikuvajaduste" üle olevikus - tähendab minevikutarbe üle, mida rahuldab kultuuriliselt instrumentaalne kirjandus - oleks kasulik valgustada ajalooliste romaanide poeetikat, neis kujutatud sootsiumi heterogeensust, kindlasti ka lugemisajalugu. Seekaudu valgustuks teravamalt need dünaamilised protsessid, mille kaudu „ajalooliku” romaani fantaasiaküllus kujundab reaalsete lugejate minevikutunnetust.

\section{Kirjandus}

A l t t o a, Villem 1973. Eduard Vilde sõnameistrina. Tallinn: Eesti Raamat.

D a vi s, Natalie Zemon 1996 [1976]. Women's history in transition: The European case. - Feminism and History. (Oxford Readings in Feminism.) Toim Joan Wallach Scott. Oxford: Oxford University Press, lk 79-104.

Der Ehste... 1861 = Der Ehste und sein Herr. Zur Beleuchtung der öconomischen Lage und des Zustandes der Bauern in Estland. Berlin: Verlag Rudolph Gaertner.

H o b s b a w m, Eric J. 1959. Primitive Rebels: Studies in Archaic Forms of Social Movement in the 19th and 20th centuries. Manchester: Manchester University Press.

Jõgi, Mall 2007. Dokumentaalromaan XX sajandi algusest. - Eduard Vilde, Mahtra sõda. Tallinn: SE\&JS, lk 415-427.

K a h k, Juhan 1958. 1858. aasta talurahvarahutused Eestis: Mahtra sõda. Tallinn: Eesti Riiklik Kirjastus.

K a n g r o, Bernard 1940. Romaani tulek meie kirjandusse. - Eesti Kirjandus, $\mathrm{nr}$ 8, lk 331-339.

Kr u u s, Hans 1927. Pühajärve sõda 1841. a. Tartu: Loodus.

L a a n e s, Eneken 2012. Vaba mees Bornhöhe „Tasujas”. Kultuurimälu, rändavad vormid ja rahvuse rajajooned. - Keel ja Kirjandus, nr 7, lk 481-498.

L u s t, Kersti 2003. Mahtra sõda. - Vikerkaar, nr 10/11, lk 121-130.

Manzoni, Alessandro 1984. On the Historical Novel [Del romanzo storico]. Transl. by Sandra Bermann. Lincoln: University of Nebraska Press.

Mi h kels o n, Ene 1994. Nime vaev. Tallinn: Eesti Raamat.

R e i n th a l, Johannes 1923. Mahtra sõda: Talurahva rahutused Põhja-Eestis teise maareformi teostamise puhul. Tallinn: Rahvaülikool.

Rig n e y, Ann 2001. Imperfect Histories: The Elusive Past and the Legacy of Romantic Historicism. Ithaca: Cornell University Press.

S a l u, Herbert 1964. Eduard Vilden historialliset romaanit. Helsinki: Suomalaisen Kirjallisuuden Seura.

S a l u, Herbert 1981. Kuhu päike ei paista. Ühiskondlikke probleeme Eduard Vilde loomingus. Stockholm: Välis-Eesti ja EMP.

S c h o r, Naomi 1978. Zola's Crowds. Baltimore: Johns Hopkins University Press.

St ol e r, Ann Laura 2002. Carnal Knowledge and Imperial Power: Race and the Intimate in Colonial Rule. Berkeley: University of California Press. 
T a l v o j a, Rait 2009. Mahtra sõjas langenute ja karistatute elulugudest. - Igihaljas Vilde. Artikleid 2005-2009. Koost ja toim Livia Viitol. Tartu: Eesti Kirjanduse Selts, lk 120-130.

T a m m, Marek 1998. Jüriöö-tekst eesti kultuuris. - Looming, nr 3, lk 401-411.

T u g l a s, Friedebert 1909. Eduard Vilde ja Ernst Peterson. - Noor-Eesti III. Tartu: Noor-Eesti kirjastus.

Vi l d e, Eduard 1949. Mahtra sõda. Neljas trükk. (Kooliväljaanne 12.) Vadstena: Kirjastus Orto.

Vil d e, Eduard 1957. Artikleid ja kirju. Tallinn: Eesti Riiklik Kirjastus.

\section{The Mahtra War(s): Representations of gender and social relations in Volume I of Eduard Vilde's historical trilogy}

Keywords: historical novel, social relations of gender, colonial violence, peasant rebellions, Eduard Vilde

This article examines the social relations of gender in Eduard Vilde's historical novel Mahtra sõda („The Mahtra War”, 1902), focused on the widespread peasant rebellions of 1858 in northern Estland. It is argued that gender is a major axis for the representation of village life as the novel analyzes the intrusion of colonial violence into a peasant family through sexual abuse of young women who worked as servants at the manor and their forced marriages, emphasizing that women's survival strategies and resistance are shown in the context of gendered social relations. The Trauerspiel of the Mahtra rebellion draws close attention not only to the event's structure and pathos, but also to its extended costs of the subsequent brutal punishment to the peasant family. Amidst the two intersecting romantic plots, the Swiss-French governess Juliette Marchand articulates Enlightenment critique of the practices of colonial violence and the institution of serfdom. Vilde's historical trilogy deserves further analysis in light of current debates concerning the poetics of the historical novel, and on the novel's contextual impact on the prodromes of the 1905 revolution.

Tiina Kirss (b. 1957), PhD, Estonian Institute of Humanities, Tallinn University, professor of cultural theory, tiina.kirss@ut.ee 